\title{
Editorial
}

\section{CONSELHOS DE ENFERMAGEM}

O Conselho de Enfermagem e os Conselhos Regionais foram criados por lei, - Lei n..$^{\circ} .905$, de 12 de julho de 1973, publicada no Diário Oficial da União de 13 de julho desse ano. Essa aspiração ùa classe data de muitos anos. Por que só agora vem a lei? O processo foi lento. As reflexões valiosas do Dr. Jurandir Lodi, então Diretor de Ensino Superior, a Presidente da ABEn, sobre a necessidade do órgão de disciplina e fiscalização do exercício profissional, muito contribuiram para que o I Congresso Brasileiro de Enfermagem, realizado em S. Paulo em 1947, recomendasse a criação dos Conselhos de Enfermagem.

A partir de 1960 começou a tramitação do projeto, que contou com inúmeros subsídios, dentre os quais o Parecer do Prof. Cesarino Junior, jurista de nomeada. O assunto foi discutido em muitas Assembléias de Delegados.

O dia 13 de julho de 1973 é um marco a ser lembrado; começou a vigorar a lei que dispõe sobre a criação dos Conselhos Federal e Regional de Enfermagem.

Ajudaram a ABEn na tramitação do projeto de lei dos Conlhos não só sua Comissão de Legislação, como enfermeiras do Rio Grande do Sul, São Paulo, Goiás, Bahia e muitos outros Estados.

É ainda motivo de justo júbilo termos unificada a profissão de enfermeiro, com respeito à especialidade de obstetrícia. A unificação completou-se em 1972, em virtude do que dispõe o Parecer n. ${ }^{\circ} 163$ iis Conselho Federal de Educação. Em decorrência desse Parecer, são enfermeiras todas as obstetrizes, daqui por diante. São três as habilitações, como se recorda: médico-cirúrgica, de obstetrícia e de saúde pública.

Também, para os fins de controle, todas as ocupações de enfermagem são abrangidas pelos Conselhos. Uma das vantagens é à integração. Todos os exercentes de enfermagem de que trata a lei n. ${ }^{0} 2.604$ de 1955, em uma determinada área, têm seu exercício regido pelo mesmo Conselho Regional. 